\title{
The Effect of Accounting Information System and Tax Socialization on the Compliance of Personal Tax Reporting (Survey at PT. Belindo International Carpet)
}

\author{
Endraria $^{1} \quad$ Rosullah Aprilian Ihsan ${ }^{2}$ \\ 1.Lecturer at the Faculty of Economics and Business, University of Muhammadiyah Tangerang, Cikokol \\ Tangerang City Pioneer Independence Road I Banten Province Indonesia \\ 2.Post-graduate Faculty of Economics Study Program, Muhammadiyah University of Tangerang
}

\begin{abstract}
With the existence of an Accounting Information System, individuals / organizations can easily make a report that will be useful in taking various decisions based on the available financial information. Tax is a very important role in the life of the state. Tax from the community is the main source of funding for the government of the Republic of Indonesia in financing development. In order to support the increase in state revenues through taxes, the government carried out a reform in the tax sector, namely the change from the Official Assessment System to the Self Assessment System, namely by applying such e-TIN, e-SPT, and e-filing. . With E-filling, it is expected that the community can comfortably and easily fill out and submit a Taxpayer Notification Letter report online, it can be done anywhere and anytime. With the ease and flexibility of this system, it is expected to increase taxpayer compliance to report the tax.
\end{abstract}

Keywords: Accounting Information System, Tax Socialization and Compliance Of Personal

DOI: $10.7176 / \mathrm{EJBM} / 11-24-08$

Publication date: August $31^{\text {st }} 2019$

\subsection{Introduction}

Technological advances, especially in the field of information technology, make market competition increasingly competitive. The complexity of accounting data is often one of the problems of individuals / organizations in making decisions, especially those related to finance. One form of technological progress in the field of information that can facilitate individuals / organizations in dealing with these problems is the application of Accounting Information Systems. According to Mujilan (2012), Accounting Information Systems (SIA) are collections of resources, such as humans and equipment, which are arranged to convert data into information. According to Aditya Kautsar (2007), Accounting Information Systems is a system (capable of) collecting, storing and processing data to produce information for decision makers, both internal and external parties, in the form of financial information. With the existence of an Accounting Information System, individuals / organizations can easily make a report that will be useful in taking various decisions based on the available financial information. Tax is a very important role in the life of the state. Tax from the community is the main source of funding for the government of the Republic of Indonesia in financing development. Tax revenue for the period January-October 2018 is Rp. 1,016.52 trillion or $71.39 \%$ of the State Budget. (Ministry of Finance, 2018). The role and awareness of the community in compliance with payment of taxes is very important in order to encourage tax revenue. In order to support the increase in state revenues through taxes, the government carried out a reform in the tax sector, namely changes from the Official Assessment System to the Self Assessment System. With the Self Assessment System, taxpayers can calculate, deposit and self-report the amount of tax in accordance with applicable laws and regulations. The Government through the Director General of Taxes makes a support system to support the smoothness of the Self Assessment System, including e-NPWP, e-SPT, and efiling. The existence of these reforms is expected to increase state revenues through taxes and create transparency in taxation.

In addition, reporting of Notification (SPT) is also one of the obligations of taxpayers. Law No. 28 of 2007 states: Every taxpayer completes a correct, complete and clear Notification in Indonesian using Latin letters, Arabic numerals, Rupiah units, signs and submits it to the Office of the Directorate General of Taxes where registered or confirmed taxpayers or other places are determined by the director tax general. Given the importance of SPT reporting, especially on individual taxpayers, it is necessary to conduct research that examines the effect of Accounting Information Systems (SIA) and tax socialization on compliance with individual taxpayer reporting (in this case the SPT).

\section{LITERATURE REVIEW}

Accounting information system. According to Aditya Kautsar (2007), Accounting Information Systems are a system (capable of) collecting, storing and processing data to produce information for decision makers, both internal and external parties, in the form of financial information. Internal parties will need more specific 
information, while external parties can use information that has been summarized. Internal parties are those most in need of AIS in the interests of the company, while external parties need SIA in the form of annual financial statements or to send confirmation to customers for the purpose of the organization or company. The available information must be read and understood by internal and external parties. Accounting Information Systems can be done with three methods, namely by using technology, manual systems or a combination of technology and manual systems.

Understanding of Taxes. According to Law No. 28 of 2007, Tax is a compulsory contribution to the state owed by an individual or entity that is compelling based on the law by not getting direct compensation and used for state needs for the greatest prosperity of the people. There are two tax functions, namely the function acceptance where tax is a source of funds for the government to finance its expenses, and functions of regulators where taxes are a tool to regulate or implement government policies in the social and economic fields (Isroah, 2013). An example of the function of tax revenue is that taxes are included in state revenues to be used as APNs, while the example of a tax regulator function is suppressing liquor by subject to high taxes.

Tax Function. According to Isroah (2013), taxes have two functions, namely: a). The function of acceptance (Budgetair) where tax is a source of funds for the government to finance its expenses, and b). Regulatory function (Regular) where tax as a tool to regulate or implement government policies in the social and economic fields (Isroah, 2013). Types of Taxes. Taxes can be divided based on the method of collection, the nature and institution of the collector. c). Based on the method of collection: Direct tax, where the tax burden is borne by the taxpayer himself and can be transferred to others. Examples are Income Tax ( $\mathrm{PPh})$, Motorized Vehicle Tax, and Land and Building Tax (PBB) 4). Indirect tax, where the tax burden can be transferred to another party because it does not have a tax assessment letter. Examples are Value Added Tax (VAT), Import Duty and Export Tax. Based on its nature, Subjective tax, which is a tax that originates or rests on the subject, in the sense of paying attention to the state of the taxpayer. Example: Income Tax. Objective tax, that is, taxes that originate on the object, regardless of the taxpayer's personal circumstances. Example: Value Added Tax and Sales Tax on Cars above 1 billion. Based on the collection agency Central Tax, namely taxes collected and managed by the Central Government through the Directorate General of Taxes (DPJ). For example Income Tax (Pph), Value Added Tax (VAT), Import Duty and Export Tax. Regional taxes, namely taxes collected and managed by the Regional Government both at the Provincial and Regency / City levels. Examples of regional taxes managed by the Province are Motor Vehicle Taxes, motor vehicle fuel taxes and surface water taxes, while the regional taxes managed by the Regency / City are hotel, restaurant, billboard, amusement parks and street lighting taxes.

Tax socialization. One of the governments in providing public education on the importance of taxes is by conducting tax socialization. Tax socialization can be done by various methods. These methods include conducting direct counseling in the field or through advertising tax services in print or electronic media. Direct counseling to the field is carried out by local tax officers who are carried out with the introduction of taxation, how to calculate taxes, how to fill in tax returns, and consultation about taxation. Tax sausage in print media can be done by installing billboards, brochures, and other print media containing tax information that is easily understood by the public. Electronic media is also one of the means of the government in taxation socialization, for example with tax socialization on radio, television, or social media that can be accessed by many people. Notification Letter (SPT). According to Law No. 28 of 2007 article 1 number 11, Notification is a letter that is used by Taxpayers to report calculations and / or assets and liabilities in accordance with the provisions of tax laws and regulations." This Notice is regulated in Law No. 28 of 2007 article 4 paragraph 1,Taxpayers must fill out and submit a notification letter correctly, completely, clearly and sign it. Broadly speaking, the function of the SPT is to report the tax payments that have been made, either independently or deducted income from the company within one year. In the SPT also reported income and property held outside of regular income. Taxpayers whose taxes have been deposited by the company will receive tax deposit proof in the form. For private employees will receive Form 1721 A1 while for PNS receive form 1721 A2. In addition to the cut proof form that the company does, there is also an Individual Income Tax Return form. For taxpayers who work without ties will get form 1770, personal taxpayers with income less or equal to Rp. 60 million a year and only work for one company will get a 1770 SS form, and a personal taxpayer earning more than Rp. 60 million a year and working for more or equal to two companies will get form $1770 \mathrm{~S}$. To fill in the SPT can be done online (eSPT) or manually. Manually filling SPT will take longer than filling electronically, because online reporting starts from counting, depositing and reporting using an integrated system. E-Filling. According to the regulations issued by the 2014 Director General of Taxes as set out in PER-01 / PJ / 2014, E-Filling is a method of submitting annual SPT electronically conducted online and real time via the internet on the website of the Directorate General of Taxes. This facility can be used for Annual Personal Tax Returns, whether using Form $1770 \mathrm{~S}$ or $1770 \mathrm{SS}$. E-filling (Electronic Filling System) is an innovation in the form of an Accounting Information System conducted by the Director General of Taxation in the field of tax reform, by utilizing information technology. E-Filling was first launched on January 24, 2005 referring to the Decree of the Director General of Tax No. Kep-88 / PJ / 2004. With E-filling, it is expected that the community can comfortably and 
easily fill out and submit a Taxpayer Notification Letter report online, it can be done anywhere and anytime. EFilling can use devices that are connected to the internet and can be accessed 24 hours a day without recognizing holidays, unlike services carried out in the tax office. With the ease and flexibility of this system, it is expected to increase taxpayer compliance to report tax returns.

\section{METHODOLOGY}

The research was conducted in the PT. Belindo International Carpet in June 2019. The company is located at Jl. Bumimas VII No. 8, Cikupa Mas Industrial Zone, Talaga Village, Cikupa District, Tangerang Regency. This type of research assignment is quantitative research. According to Kuncoro (2003), this study uses data in the form of numbers to explain the results of his research and usually uses statistics in processing data. The data used is in the form of choices through a questionnaire. The technique of collecting data through the questionnaire will be used as primary data. Panelists will be presented with a number of statements and given the choice between strongly agreeing and strongly disagreeing. In addition to primary data, in this task there will also be supporting data in the form of secondary data. Secondary data is data obtained from research companies, namely PT. Belindo International Carpet.

\section{RESULTS AND DISCUSSION}

\subsection{Analysis Results}

Test Validity.Validity test is testing each questionnaire with a correlation value with a minimum value of 0.3 . If the results obtained are less than 0.3 then the data is invalid, whereas if the results obtained are equal to or more than 0.3 then the data is valid.

Table 1 Test Results for Validity of Accounting Information Systems

\begin{tabular}{|c|c|c|}
\hline Statement & Pearson Correlation & Results \\
\hline 1 & 0,899 & Valid \\
\hline 2 & 0,93 & Valid \\
\hline 3 & 0,958 & Valid \\
\hline 4 & 0,924 & Valid \\
\hline 5 & 0,827 & Valid \\
\hline 6 & 0,899 & Valid \\
\hline 7 & 0,93 & Valid \\
\hline 8 & 0,958 & Valid \\
\hline 9 & 0,924 & Valid \\
\hline
\end{tabular}

Source: Results of SPSS Data Processing, 2019

Table 2 Test Results for Validity of Taxation Socialization

\begin{tabular}{|c|c|c|}
\hline Statement & Pearson Correlation & Results \\
\hline 1 & 0,838 & Valid \\
\hline 2 & 0,923 & Valid \\
\hline 3 & 0,921 & Valid \\
\hline 4 & 0.924 & Valid \\
\hline 5 & 0,923 & Valid \\
\hline 6 & 0,905 & Valid \\
\hline
\end{tabular}

Source: Results of SPSS Data Processing, 2019

Table 3 WPOP Reporting Compliance Validity Test Results

\begin{tabular}{|c|c|c|}
\hline Statement & Pearson Correlation & Results \\
\hline 1 & 0,935 & Valid \\
\hline 2 & 0,957 & Valid \\
\hline 3 & 0,935 & Valid \\
\hline 4 & 0.872 & Valid \\
\hline 5 & 0,935 & Valid \\
\hline 6 & 0,957 & Valid \\
\hline
\end{tabular}

Source: Results of SPSS Data Processing, 2019

The Reliability Test, If the value of Cronbach's alpha obtained in the results of Reliability $>0.6$, the data can be said to be reliable, whereas if the value of Cronbach's alpha is obtained $>0.6$ then the data is not reliable. 


\begin{tabular}{|l|c|c|}
\hline \multicolumn{1}{|c|}{ Variabel } & Croanbach's Alpha & Hasil \\
\hline X1 (Accounting Information System) & 0,975 & Reliabel \\
\hline X2 (Tax Information) & 0,956 & Reliabel \\
\hline Y (WPOP Reporting Compliance) & 0,969 & Reliabel \\
\hline
\end{tabular}

From the results of the reality, it can be concluded that the statement used as a measurement tool in this research assignment is reliable.

\subsection{Clastic Assumption Test}

Normality test. Normality test is used to find out whether the data used has been distributed normally or not. The normality test is obtained from processing using the SPSS application. From the questionnaire results, the normality test is obtained as follows :

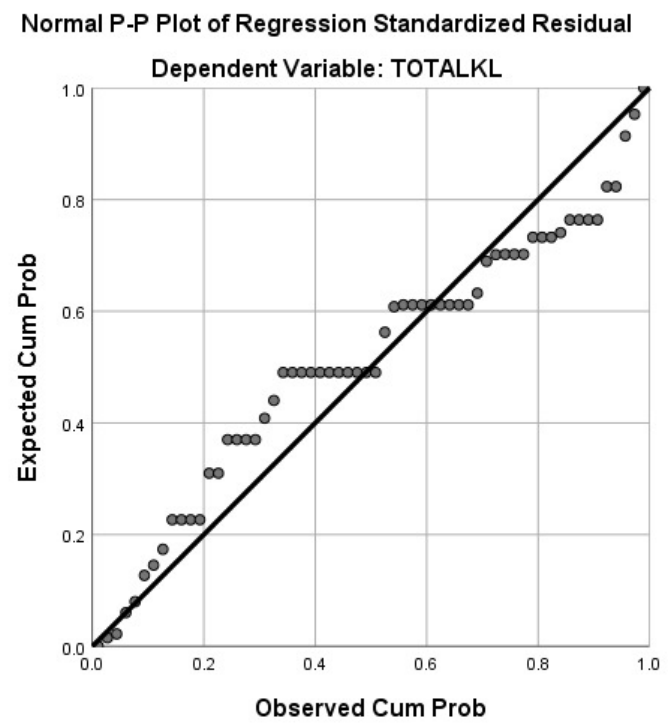

Figure 1 Normality Test Results

Source: Results of SPSS Data Processing, 2019

From the picture above it can be seen that the resulting data spreads and follows the direction of the diagonal line. This proves that the data used is normally distributed and has met the standard assumption of normality.

Heteroscedasticity Test. Heteroscedasticity test is a test to prove whether there is an inequality of variants of residuals in the regression model. Detection of heteroscedasticity by looking at the dot pattern on the regression scatterplots. If the points spread with an unclear pattern above and below the zero on the Y axis, then the data used is not a problem with heteroscedasticity. From the results of the questionnaire, the heteroscedastity test was obtained using SPSS as follows:

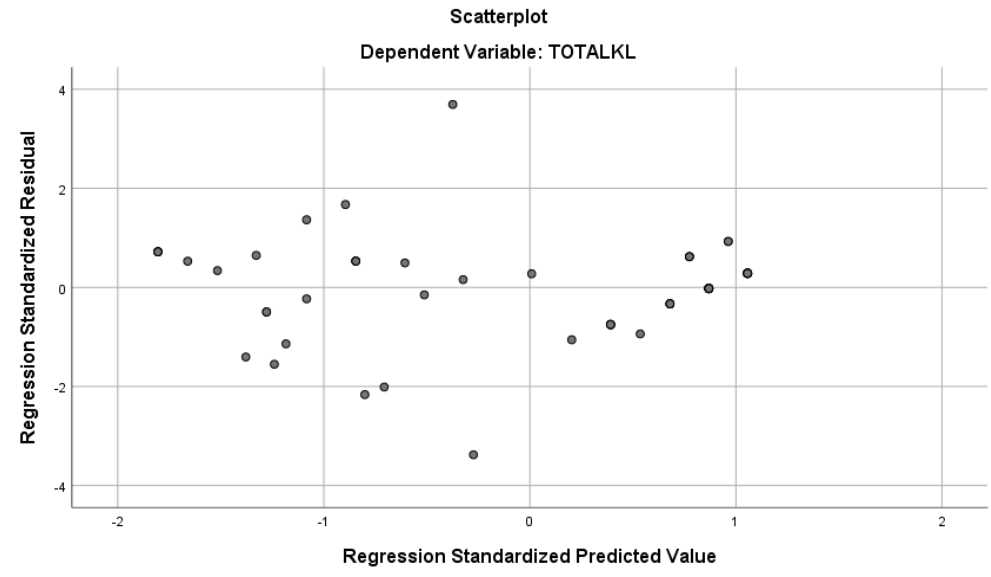

Figure 2 Heteroscedasticity Test Results

Source: Results of SPSS Data Processing, 2019

From the picture above it can be seen that the resulting data spreads and follows the direction of the diagonal line. This proves that the data used is normally distributed and has met the standard assumption of 
normality.

Heteroscedasticity Test. Heteroscedasticity test is a test to prove whether there is an inequality of variants of residuals in the regression model. Detection of heteroscedasticity by looking at the dot pattern on the regression scatterplots. If the points spread with an unclear pattern above and below the zero on the Y axis, then the data used is not a problem with heteroscedasticity. From the results of the questionnaire, the heteroscedastity test was obtained using SPSS.

Autocorrelation Test. The autocorrelation test is a test to see whether in a regression model there is a correlation between interfering errors in period $t$ with errors in the period $t-1$ (before). A good regression model is free from autocorrelation, that is, with the Durbin Watson (DW) statistic value between -2 to +2 . From the results of the questionnaire, the autocorrelation test was obtained using SPSS as follows:

\section{Table 5 Autocorrelation Test Results}

Model Summary ${ }^{b}$

\begin{tabular}{|l|r|r|r|r|r|}
\hline Model & R & R Square & Adjusted R Square & Std. Error of the Estimate & Durbin-Watson \\
\hline 1 & $.954 \mathrm{a}$ & .910 & .907 & 2.18258 & 1.921 \\
\hline
\end{tabular}

a. Predictors: (Constant), TOTALSP, TOTALSIA

b. Dependent Variable: TOTALKL

Source: Results of SPSS Data Processing, 2019

From the table of correlation test results above, it can be concluded that the data from this study are free from autocorrelation, because the DW value between -2 and +2 is 1,921 .

Multicollinearity Test. Multicollinearity test aims to see whether the regression model used is found to have a correlation between independent variables. If the tolerance value is $>0.1$ or VIF value is $<10$, the model is free from multicollinearity. From the results of the questionnaire, the multicollinearity test was obtained using SPSS as follows:

Table 6 Multicollinearity Test Results

Coefficients $^{\text {a }}$

\begin{tabular}{|r|l|r|r|}
\hline \multirow{2}{*}{\multicolumn{2}{|l|}{ Model }} & \multicolumn{2}{c|}{ Collinearity Statistics } \\
\cline { 3 - 4 } & Tolerance & \multicolumn{1}{c|}{ VIF } \\
\hline 1 & (Constant) & & \\
\hline & TOTALSIA & 110 & 9.982 \\
\hline & TOTALSP & 110 & 9.982 \\
\hline
\end{tabular}

a. Dependent Variable: TOTALKL

Source: Results of SPSS Data Processing, 2019

From the results of the multicollinearity test it can be concluded that there is no correlation in each independent variable.

\subsection{Hypothesis Testing}

Partial Test (t-Test). Partial Test (t-Test) is used to find out whether there is an influence between each independent variable and the dependent variable. From the results of the questionnaire it was obtained the Paris test (t-test) using SPSS as follows:

Table 7 Partial Test Result Tables (t-Test)

Coefficients $^{\mathrm{a}}$

\begin{tabular}{|c|c|r|r|r|r|r|}
\hline \multirow{2}{*}{ Model } & \multicolumn{2}{|c|}{ Unstandardized Coefficients } & Standardized Coefficients & & \\
\cline { 3 - 7 } & B & Std. Error & Betta & t & Sig. \\
\hline 1 & (Constant) & 1.483 & .832 & & 1.782 & .080 \\
\hline & TOTALSIA & .460 & .166 & .773 & 2.154 & .012 \\
\hline & TOTALSP & .185 & .123 & .189 & 1.666 & .013 \\
\hline
\end{tabular}

a. Dependent Variable: TOTALKL

Source: Results of SPSS Data Processing, 2019

From the results of partial testing (t-test) above it can be explained the effect of each independent variable on the dependent variable. The first is the effect of the Accounting Information System on the Compliance of Individual Taxpayer Reporting. From the results of the T-Test conducted, the Accounting Information System (SIA) has a significance value smaller than 0.05 , which is 0.012 with $t$ count of 2.154 and table 1.664 . The calculation obtained is greater than $\mathrm{T}$ table. Therefore it can be concluded that partially the Accounting Information System has an influence on Individual Taxpayer Reporting Compliance because it has a significance value smaller than 0.05 and Thitung is greater than $\mathrm{T}$ table. The second is the submission of Taxation Information Session to Compliance with Individual Taxpayer Tax Reporting. From the results of the T-test conducted, Tax Socialization has a significance value smaller than 0.05 , which is 0.013 with Tcount of 1.666 and Ttable 1.664. The calculation obtained is greater than $\mathrm{T}$ table. Therefore, it can be concluded that Tax 
Socialization has a significant influence on Individual Taxpayer Reporting Compliance because it has a significance value smaller than 0.05 and Thitung is greater than T table.

Significant Test of Stimultan (Test-F). The F test is used to determine the feasibility of the research model used as an analytical tool. If the significance value is less than 0.05 then the independent variable is worthy of being used as an analysis tool. . From the results of the questionnaire, the F-Test was obtained using SPSS as follows:

Table 8 Significant Stimultan Test Results (F-Test)

\begin{tabular}{|c|c|c|c|c|c|}
\hline Model & Sum of Squares & df & Mean Square & $\mathbf{F}$ & Sig. \\
\hline Regression & 43.411 & 3 & 14.470 & 4.666 & $.005^{\mathrm{b}}$ \\
\hline Residual & 249.441 & 74 & 3.3370 & & \\
\hline Total & 292.852 & 77 & & & \\
\hline
\end{tabular}

a. Dependent Variable: TOTALKL

b. Predictors: (Constant), TOTALSP, TOTALSIA

Source: Results of SPSS Data Processing, 2019

From these results obtained Fcount of 4.666 which has a significance level of 0.005 . Based on these results, the regression model can be used because it has a significance level below 0.05 .

\section{Conclusion}

Based on the results of research that has been done, it can be concluded that:

1. Accounting Information System has a significant effect on Reporting Taxpayer Compliance at PT. Belindo International Carpet

2. Tax Dissemination has a significant effect on Reporting Obligations of Individual Taxpayers at PT. Belindo International Carpet.

\section{REFERENCES}

Aditya, Kautsar (2007). Accounting Information System: An Introduction.University of MercuBuana. Jakarta.

Director General of Taxes. (2013). Director General of Tax Regulation Number PER-36 / PJ / 2011 which has been updated with the latest Director General Tax Regulations, Number PER-1 / PJ / 2014 concerning procedures for submitting Notification for Individual Taxpayers using form 1770S or 1770SS e- filing through the website of the Directorate General of Taxes. (www.pajak.go.id). Jakarta

Isroah.(2013). Taxation.UMY.Yogyakarta.

Ministry of Finance.(2018). Our State Budget Works and Facts.KEMENKEU. Jakarta.

Mujilan, Augustine. (2012) Accounting Information Systems: Theories and Insights in the Electronic World. Widya Mandala Press. Madiun.

Lovihan, Siska. (2011) Effect of Tax Paying Awareness, Knowledge and Understanding of Tax Regulations, and Service Quality on the Willingness to Pay Personal Tax Payers in Tomohon City. Available at: https://media.neliti.com/media/publications/61638-ID-paruh-kesadaran-membayar-pajak-penget.pdf (Accessed on June 15, 2019 at 15.10 WIB).

Putu, L. \& Lely, N.K. (2018) Effect of Taxpayer Awareness, Tax Sanctions, E-Filing, and Tax Amnesty on Taxpayer Reporting Compliance. Accounting E-Journal of Udayana University Vol 22.2 ISSN: 2302-8556

Republic of Indonesia.(2007). Law No. 28 of 2007 concerning the third amendment to Law No. 6 of 1983 concerning general provisions and procedures for taxation. Jakarta.

Suherman, M ,. Almunawwaroh, M. \&Marliana, R. (2015).The Effect of E-Filing Application on Taxpayer Compliance in Submission of Annual Notification Letter to the Pratama Tax Service Office of Tasikmalaya City.Media Research Accounting, Auditing \& Information, Udayana University, Vol. 15 No. April 1, 2015.

Wahyu, Eka. (2010) The Effect of Taxation Socialization on Compliance with Reporting for Individual Annual Annual Tax Returns in the Office of Service, Counseling and Tax Consultation (Kp2kp) of Sragen. SebelasMaret University. Surakarta. 